\title{
A07
}

\section{Hydrocarbon Prospectivity and Play Types of the Levantine Basin from Modern Seismic Data}

D. Rowlands* (Spectrum Energy and Information Technology), G. Roberts (Spectrum Energy and Information Technology) \& D. Peace (SD

Exploration Services)

\section{SUMMARY}

The paper describes the regional tectonic setting and evolution of the Levantine basin in the Eastern Mediterranean. Thereafter the majority of the paper focuses on the hydrocarbon prospectivity and play types in the basin derived from an interpretation of $20,000 \mathrm{~km}$ of modern, high quality seismic data. 
The Levantine Basin is the easternmost part of the East Mediterranean Basin. It sits on the northern edge of the African Plate and runs north and north eastwards from the Nile Delta to Cyprus where the African Plate meets the Eurasian Plate and has formed a thrust belt known as the Cyprus Arc. North of this thrust belt are 'piggy-back' basins such as the Latakia Trough, Iskenderun. Adana and Cilicia basins.

The Levantine Basin's northern boundary is defined by Cyprus and the Larnaca/Latakia Ridge, the north western margin is defined by onlap onto the Eratosthenes Seamount and the south western margin by the Nile Delta Cone. Its eastern edge is defined by the present day East Mediterranean coast.

The Levantine Basin can therefore be defined as a foreland basin. Evidence from seismic and other geophysical studies shows that it contains over 10kms thickness of Mesozoic to Recent sediments above a rifted Triassic Early Jurassic terrain. The Mesozoic section shows evidence of both contraction and expansion due to plate motion, salt tectonics and other gravitational processes.

\section{ii) Hydrocarbon Prospectivity}

The Levantine Basin is at a very immature stage of petroleum exploration, with no exploration wells having been drilled offshore Lebanon, Syria or Cyprus.

This paper is based on an analysis of over $20,000 \mathrm{kms}$ of $2 \mathrm{D}$ seismic data collected/processed by GGS-Spectrum and its co-venturers. It concentrates on describing the plays offshore two of the overlooked countries: Lebanon and Syria.

These plays consist of:

- Jurassic and older: faulted structures, rollovers and basin margin plays

- Upper Jurassic to Middle Cretaceous: mounds, reefs, progrades, drape structures, structural/stratigraphic plays and unconformity plays

- Middle Cretaceous to Lower Tertiary: anticlines, fault blocks, rollovers, mounds, drapes, structural/stratigraphic plays and basin margin pinch-outs.

- Intra Salt (Messinian): bright spots and channels

- Post Salt (Plicoene to recent): channels/mounds

The seismic data shows a number of Direct Hydrocarbon Indicators (bright spots, flat spots and gas chimneys), whilst evidence from a satellite seep survey over he Eastern Mediterranean shows seeps to be widespread (over), indicating hydrocarbon prospectivity in the Basin. The paper also describes potential source rocks and seals in the basin. 